\title{
Predictors of duodenal ulcer healing during treatment with cimetidine
}

\author{
M Okada, T Yao, K Maeda, T Yamamoto, K Saigenji, Y Okada, K Sakamoto, K Tanaka
}

\begin{abstract}
A two phase study was performed to identify factors that influence the healing rate of duodenal ulcer. The study included an initial clinical trial in 145 patients and a second trial in a further 61 patients. All patients were prescribed cimetidine at a daily dose of $800 \mathrm{mg}$ for six weeks. The factors examined were age, sex, inpatient or outpatient treatment, duration of present ulcer pain, past history of duodenal ulcer, smoking, drinking, the length of time it took for symptoms to resolve after beginning treatment, and the characteristics of the ulcers themselves.
\end{abstract}

Eighty four per cent of the duodenal ulcers healed after six weeks. Using univariate and multivariate analyses, it was found that three factors indicated a significant delaying effect on healing: (1) symptoms that persisted two weeks after treatment had begun; (2) heavy smoking (20 or more cigarettes daily); and (3) severe narrowing of the duodenal bulb. Patients with none of the three unfavourable factors $(n=90)$ had a healing rate of $95.6 \%$ compared with patients with one $(n=45)$ or two or more $(n=10)$ factors, whose healing rates were $75.6 \%$ and $20.0 \%$ respectively $(p<0.001)$. The corresponding figures in a second study were $88.9 \%, 55.0 \%$, and $0 \%$, respectively $(\mathbf{p}<0.001)$. A prognostic score based on these three factors represents the severity of duodenal ulcers with regard to healing in patients treated with cimetidine.

Department of Internal Medicine and

Gastroenterology,

Fukuoka University

Chikushi Hospital,

Chikushino-shi, Fukuoka

818, Japan

M Okada

T Yao

K Maeda

T Yamamoto

Department of Internal Medicine, School of Medicine, Kitasato University, Japan K Saigenji

Department of Internal Medicine, Fukuoka Red Cross Hospital, Japan Y Okada

Department of Internal Medicine, Kyushu Central Hospital, Japan K Sakamoto

Fukuoka City Ishikai Hospital, Japan K Tanaka

Correspondence to: Dr Mistuo Okada.

Accepted for publication 18 September 1989

Although there have been a number of studies of the effect of drugs on duodenal ulcers, there are fewer reports on the effects of other factors on duodenal ulcer healing. This is because of the small number of patients studied, which has been enough to allow drug assessment but not sufficient to assess other factors. ${ }^{1} \mathrm{H}_{2}$ receptor antagonists have led to dramatic improvements in the healing rate of duodenal ulcers. Intractable or refractory duodenal ulcers are ulcers that have not healed after eight weeks ${ }^{2}$ or three months respectively of full dose treatment with a modern antiulcer drug. These ulcers are relatively rare, which makes assessment of predictors of duodenal ulcer healing under treatment with $\mathrm{H}_{2}$ receptor antagonists difficult.

Identifying patients with slow healing duodenal ulcer before or soon after starting treatment would have therapeutic and economic value, and would help to elucidate the factors that affect duodenal ulcer healing as well as those that underlie its pathophysiology. ${ }^{4}$ The aim of the present study was to elucidate factors that influence the healing rate of duodenal ulcer during treatment with cimetidine and to identify patients with a refractory duodenal ulcer.

\section{Patients and methods}

A two phase study was performed to elucidate predictors of duodenal ulcer healing and identify patients with refractory duodenal ulcer.

\section{PHASE 1}

One hundred and forty five patients with duodenal ulcer diagnosed at our clinic between July 1985 and August 1986 were entered into the trial. We excluded: patients aged over 75 years and under 16 years; pregnant women; patients with chronic liver or renal disease, or any other severe disease; patients who regularly used acetylsalicylic acid or other ulcerogenic drugs; those with a past history of ulcer surgery; patients with gastric ulcer; patients with ulcer size of less than $4 \mathrm{~mm}$; and patients who had taken antiulcer drugs within four weeks of the start of the study. Informed consent was obtained from all patients.

Treatment started within $\mathbf{4 8}$ hours of endoscopy. All patients were treated with cimetidine, $200 \mathrm{mg}$ four times a day. Treatment was given on either an outpatient or inpatient basis. Endoscopy was repeated at three week intervals until ulcer healing was confirmed. An ulcer was regarded as healed when complete epithelialisation of the ulcer had been achieved, as determined by endoscopy. Ulcer size was assessed by measuring the greatest diameter with the tip of an open forceps. In patients with several ulcers the diameter of the largest ulcer was measured. with the surrounding mucosa were classified as 'flat', those with a clearly depressed base more than $4 \mathrm{~mm}$ from the margin were 'deep', and ulcers whose extent was between these two were described as 'moderate'. The degree of deformity of the duodenal bulb was scored ${ }^{4}: 3=$ narrowing of the entrance or exit of the duodenal bulb by scarring, but still admitting the endoscope (external diameter $=9 \mathrm{~mm}$ ); $2=$ bilatera deformity; $1=$ unilateral deformity of bulb; $0=$ no deformity. All endoscopic findings were registered immediately after each endoscopy. The endoscopists were not aware of the clinical progress of the patients.

The patients recorded information on drug ingestion. The duration of the present ulcer pain was dated from the start of the present ulcer-like symptoms. Each patient was questioned about their ulcer symptoms every two weeks to determine when they had resolved.

The following characteristics were compared in patients whose ulcers healed within six weeks 
TABLE I Characteristics of patients with healed $(n=122)$ and unhealed $(n=23)$ duodenal ulcers

\begin{tabular}{|c|c|c|c|}
\hline & \multicolumn{2}{|c|}{ Duodenal ulcer group } & \multirow[b]{2}{*}{ Significance } \\
\hline & Healed $^{\star}$ & Unhealedt & \\
\hline Age (years) (mean (SD)) & $39 \cdot 1(12 \cdot 9)$ & $36.0(10 \cdot 0)$ & NS \\
\hline \multicolumn{4}{|l|}{ Sex: } \\
\hline $\begin{array}{l}\text { Men } \\
\text { Women }\end{array}$ & $\begin{array}{l}83 \\
39\end{array}$ & $\begin{array}{r}20 \\
3\end{array}$ & $\mathrm{p}=0 \cdot 11$ \\
\hline \multicolumn{4}{|l|}{ Treatment basis: } \\
\hline $\begin{array}{l}\text { Inpatient } \\
\text { Outpatient }\end{array}$ & $\begin{array}{l}31 \\
91\end{array}$ & $\begin{array}{r}3 \\
20\end{array}$ & NS \\
\hline Duration of present ulcer symptoms & $63 \cdot 7(337 \cdot 4)$ & $149 \cdot 0(380 \cdot 3)$ & NS \\
\hline \multicolumn{4}{|l|}{ Past history of duodenal ulcer: } \\
\hline $\begin{array}{l}\text { Yes } \\
\text { No }\end{array}$ & $\begin{array}{l}65 \\
53\end{array}$ & $\begin{array}{r}12 \\
9\end{array}$ & NS \\
\hline \multicolumn{4}{|c|}{$\begin{array}{l}\text { Resolution of symptoms within } 2 \text { weeks } \\
\text { of starting treatment: }\end{array}$} \\
\hline $\begin{array}{l}\text { Yes } \\
\text { No }\end{array}$ & $\begin{array}{r}111 \\
11\end{array}$ & $\begin{array}{r}14 \\
9\end{array}$ & $\mathrm{p}<0.001$ \\
\hline \multicolumn{4}{|l|}{$\begin{array}{l}\text { Number of cigarettes smoked per day } \\
(\text { mean }(\mathrm{SD})) \text { : }\end{array}$} \\
\hline $\begin{array}{l}\text { Before treatment } \\
3 \text { weeks after starting treatment } \\
6 \text { weeks after starting treatment }\end{array}$ & $\begin{array}{c}12 \cdot 0(12 \cdot 8) \\
7 \cdot 9(10 \cdot 6) \\
7 \cdot 5(9 \cdot 5)\end{array}$ & $\begin{array}{l}20 \cdot 7(12 \cdot 9) \\
15 \cdot 6(11 \cdot 6) \\
13 \cdot 6(9 \cdot 5)\end{array}$ & $\begin{array}{l}\mathrm{p}<0.01 \\
\mathrm{p}<0.01 \\
\mathrm{p}<0.01\end{array}$ \\
\hline \multicolumn{4}{|l|}{ Alcohol consumption (g/day) } \\
\hline $\begin{array}{l}\text { Before treatment } \\
3 \text { weeks after starting treatment } \\
6 \text { weeks after starting treatment }\end{array}$ & $\begin{array}{l}27(36) \\
12(27) \\
15(27)\end{array}$ & $\begin{array}{l}39(39) \\
24(36) \\
21(36)\end{array}$ & $\begin{array}{l}p=0 \cdot 12 \\
p=0 \cdot 07 \\
\text { NS }\end{array}$ \\
\hline
\end{tabular}

«Ulcers which healed within six weeks of starting treatment.

+Ulcers which did not heal within six weeks of starting treatment.

of starting treatment and in patients whose ulcers did not heal in this time: age; sex; whether treated as in- or outpatients; duration of present ulcer symptoms; past history of duodenal ulcer; number of cigarettes smoked; the amount of alcohol consumed before and during treatment; the length of time before symptoms resolved after starting treatment; compliance; endoscopic findings such as ulcer size, depth, number, and site of ulcer; and Sakita's endoscopic staging system. ${ }^{56}$

The relation between ulcer healing and these variables was examined initially using $\chi^{2}$ test with Yates's correction and unpaired Student's $t$ test, and subsequently by multiple stepwise linear regression analysis in which healing within six weeks was the dependent variable. ${ }^{78}$ All factors that were statistically unfavourable for duodenal ulcer healing were weighted equally and were used to calculate a prognostic score. ${ }^{910}$ The $\chi^{2}$ test by Dorn ${ }^{11}$ was used to compare the incidence among groups of more than three.

PHASE 2

To confirm the reliability of the effect of the unfavourable factors determined in phase 1 , a further series of 61 patients diagnosed at our clinic between November 1987 and June 1988 were recruited by the same criteria. The protocol was exactly the same as in phase 1 .

\section{Results}

PHASE 1 STUDY

Ulcers healed within six weeks of starting treatment in 122 of the 145 patients $(84 \cdot 1 \%)$ studied.

Table I shows the characteristics of patients with healed and unhealed duodenal ulcers. Smoking before and during treatment and the time it took for symptoms to resolve were significantly important - heavy smokers and patients in whom symptoms did not resolve within two weeks of starting treatment had a significantly poorer healing rate. The patients' sex and their alcohol ingestion had some effect on the healing rate, but these values did not reach the threshold of significance. Variables of age, whether treated as in- or outpatients, the duration of the present ulcer pain, and a past history of duodenal ulcer did not correlate with the healing rate.

The relation between the number of cigarettes smoked daily during treatment and the healing rate is shown in Table II. Patients who smoked more than 20 cigarettes daily had a significantly poorer healing rate. Thirty four of 61 patients who smoked more than 20 cigarettes daily before the treatment continued to smoke more than 20 cigarettes daily and the remaining 27 patients cut down on cigarettes during the treatment. The healing rates for these two groups were $64.7 \%$ and $85 \cdot 7 \%$, respectively $(p=0 \cdot 1303)$.

The degree of compliance with treatment was equally high in both healed and non-healed ulcer groups. Both groups showed a compliance of more than $90 \%$ during the entire period of the study.

Among the endoscopic findings, the degree of deformity of the duodenal bulb was the only significant factor influencing the healing rate (Table III). An ulcer associated with severe narrowing was significantly slower to heal. The numbers of ulcers, their shape, size, depth, site, and the stage of duodenal ulcers had no effect on the healing.

Table IV shows the results of multiple linear regression analysis. The following three factors were significant in delayed healing: symptoms that did not resolve within two weeks of beginning treatment $(\mathrm{p}<0.01)$; smoking more than 20 cigarettes per day during treatment $(\mathrm{p}<0.01)$; severe narrowing of duodenal bulb $(\mathrm{p}<0.01)$. When these factors were taken into account other factors were not significant.

The prognostic scoring system was one in which each unfavourable factor was given equal weight. The patients with varying numbers of a total of three unfavourable factors were classified into four groups (Table V). With increases in the prognostic score, the healing rate decreased from $95.6 \%$ (score of 0 ) to $75.6 \%$ (score of 1 ) to $20.0 \%$ (score of 2 and 3$)(\mathrm{p}<0.001)$.

\section{PHASE 2 STUDY}

Duodenal ulcers healed in 43 of the $61(70 \cdot 5 \%)$ patients within six weeks of beginning treatment. The healing rate six weeks after beginning treatment (depending on the number of unfavourable factors present) is shown in Table VI. With increases in the prognostic score, the healing rate decreased from $88 \cdot 9 \%$ (score of 0 ) to

TABLE II No of cigarettes smoked daily during treatment and healing rate in patients with duodenal ulcer

\begin{tabular}{llll}
\hline & \multicolumn{3}{l}{ No cigarettes per day } \\
\cline { 2 - 4 } & $0-9$ & $10-19$ & $\leqslant 20$ \\
\hline Healed ulcer & 58 & 42 & 22 \\
Unhealed ulcer & 4 & 7 & 12 \\
Healing rate (\%) & $93 \cdot 5$ & $85 \cdot 7$ & $64 \cdot 7$ \\
\hline
\end{tabular}

$\mathrm{p}<0.001$ 
TABLE III Endoscopic findings in patients with healed $(n=122)$ and unhealed $(n=23)$ duodenal ulcers

\begin{tabular}{|c|c|c|c|}
\hline \multirow[b]{2}{*}{ Endoscopic findings } & \multicolumn{2}{|c|}{ Duodenal ulcer group } & \multirow[b]{2}{*}{ Significance } \\
\hline & Healed $\star$ & Unhealed $t$ & \\
\hline \multicolumn{4}{|l|}{ Ulcer shape: } \\
\hline $\begin{array}{l}\text { Round or oval } \\
\text { Irregular }\end{array}$ & $\begin{array}{r}115 \\
7\end{array}$ & $\begin{array}{r}22 \\
1\end{array}$ & NS \\
\hline Ulcer size $(\mathrm{mm})($ mean $(\mathrm{SD}))$ & $8(3)$ & $9(4)$ & NS \\
\hline \multicolumn{4}{|c|}{ Ulcer depth: } \\
\hline Flat & 31 & 3 & \\
\hline Intermediate & 76 & 14 & NS \\
\hline Deep & 15 & 6 & \\
\hline \multicolumn{4}{|l|}{ Number of ulcers: } \\
\hline $\begin{array}{l}\text { One } \\
\text { Multiple }\end{array}$ & $\begin{array}{l}89 \\
33\end{array}$ & $\begin{array}{r}18 \\
5\end{array}$ & NS \\
\hline \multicolumn{4}{|l|}{ Bulbar deformity; range } \\
\hline $\begin{array}{l}\text { 0 3(mean (SD)): } \\
\text { None } \\
\text { Slight } \\
\text { Moderate } \\
\text { Severe }\end{array}$ & $\begin{array}{l}1 \cdot 2(0 \cdot 8) \\
24 \\
52 \\
41 \\
5\end{array}$ & $\begin{array}{l}1 \cdot 9(1 \cdot 0) \\
2 \\
6 \\
8 \\
7\end{array}$ & $\mathrm{p}<0.01$ \\
\hline \multicolumn{4}{|l|}{ Ulcer site: } \\
\hline $\begin{array}{l}\text { Anterior } \\
\text { Other }\end{array}$ & $\begin{array}{l}83 \\
39\end{array}$ & $\begin{array}{r}16 \\
7\end{array}$ & NS \\
\hline $\begin{array}{l}\text { Stage classification of ulcer: } \\
\mathbf{A}_{1} \\
\mathbf{A}_{2} \\
\mathbf{H}_{1}\end{array}$ & $\begin{array}{l}45 \\
47 \\
30\end{array}$ & $\begin{array}{r}9 \\
11 \\
3\end{array}$ & NS \\
\hline
\end{tabular}

ఓUlcer which healed within six weeks after starting treatment. †Ulcer which did not heal within six weeks of starting treatment.

$55 \cdot 0 \%$ (score of 1 ), to $0 \%$ (score of 2 and 3 ) $(\mathrm{p}<0.001)$.

\section{Discussion}

Previous attempts at identifying factors that influence the healing rate of peptic ulcers have been criticised for not being composite and comprehensive enough ${ }^{12}$ to evaluate factors that are often interrelated. It is generally recognised that multivariate analysis is necessary for evaluation of predictors of peptic ulcer healing. ${ }^{1} 9^{1} 10^{13-19}$

There are eight reports of a multifactorial analysis of duodenal ulcer. ${ }^{149} 9^{15-19}$ These studies were conducted with antacids, ${ }^{915} 16 \mathrm{H}_{2}$ receptor antagonist, ${ }^{41719}$ placebo, ${ }^{4}$ or as controlled trials comparing $\mathrm{H}_{2}$ receptor antagonist with other drugs. ${ }^{18}$ When predictors of delayed healing are identified in a group, a further study using a new group should be done to determine the reliability of the predictors found in the first study. Most studies, except a few, ${ }^{4916}$ did not include a second phase as we have done.

Our results show that three factors - symptoms persisting longer than two weeks after beginning treatment, severe narrowing of the duodenal bulb, and smoking over 20 cigarettes daily during the treatment - had a significant delaying effect on duodenal ulcer healing. This was shown in both univariate and multivariate analyses. Two weeks after beginning treatment with cimetidine, patients with duodenal ulcer could be divided into three groups to predict ulcer healing: patients with none of the three unfavourable factors had ulcers that healed

TABLE IV Multiple stepwise regression analysis related to ulcer healing within six weeks after starting treatment with cimetidine

\begin{tabular}{|c|c|c|c|c|}
\hline Step factor & Unfavourable & $\begin{array}{l}\text { Standardised } \\
\text { coefficient }\end{array}$ & Fvalue & Significance \\
\hline $\begin{array}{l}1 \text { Resolution of symptoms within two } \\
\text { weeks of treatment } \\
2 \text { Heavy smoking ( } \geq 20 \text { cigarettes daily) } \\
3 \text { Bulbar deformity } \\
4 \text { Ulcer size }\end{array}$ & $\begin{array}{l}\text { No } \\
\text { Yes } \\
\text { Severe narrowing } \\
\text { Large }\end{array}$ & $\begin{array}{l}0 \cdot 468 \\
0 \cdot 206 \\
0 \cdot 190 \\
0.080\end{array}$ & $\begin{array}{r}44 \cdot 19 \\
8 \cdot 40 \\
7 \cdot 30 \\
1 \cdot 29\end{array}$ & $\begin{array}{l}\mathrm{p}<0.01 \\
\mathrm{p}<0.01 \\
\mathrm{p}<0.01 \\
\text { NS }\end{array}$ \\
\hline
\end{tabular}

TABLE V Duodenal ulcer healing within six weeks after starting treatment with cimetidine by number of unfavourable factors

\begin{tabular}{|c|c|c|c|c|}
\hline \multirow[b]{2}{*}{ Patients group } & \multicolumn{4}{|l|}{ Score } \\
\hline & 0 & 1 & 2 & 3 \\
\hline $\begin{array}{l}\text { Healed ulcer } \\
\text { Unhealed ulcer }\end{array}$ & $\begin{array}{r}86 \\
4\end{array}$ & $\begin{array}{l}34 \\
11\end{array}$ & 2 & $\begin{array}{l}0 \\
1\end{array}$ \\
\hline Healing rate $(\%)$ & $95 \cdot 6$ & 75.6 & & \\
\hline
\end{tabular}

$\mathrm{p}<0.001$

quickly; the patients with more than two factors had intractable ulcers; and those with one of the factors had an intermediate ulcer healing rate. This was confirmed by a second series of patients with duodenal ulcer.

Calculations of prognostic indicators should be simple, and the indicators should reflect the prognosis correctly. In fact, the simple activity index proposed by Harvey and Bradshaw ${ }^{20}$ and that of the International Organisation for the Study of Inflammatory Bowel Disease (IOIBD) ${ }^{21}$ are widely used for the assessment of clinical activity in patients with Crohn's disease and correlate strongly with a Crohn's disease activity index. ${ }^{22} \mathrm{~A}$ prognostic score of duodenal ulcer by Lam and $\mathrm{KoO}^{4}$ and Massarrat et $\mathrm{al}^{16} \mathrm{can}$ be calculated using corresponding discriminant scores based on various characteristics. It is very difficult, however, for the physician in the outpatient clinic to use these for individual patients because the calculations are cumbersome. The prognostic score suggested in this study is both simple to use and accurate.

Patient compliance with drug treatment is very important in evaluating the failure of duodenal ulcers to heal. ${ }^{23}{ }^{24}$ There was no difference in compliance between the healed and nonhealed ulcer groups in this study so we did not consider compliance as a factor to be considered.

It is noteworthy that ulcer healing was delayed in patients whose symptoms persisted two weeks after the start of treatment with cimetidine. Massarrat et $a^{16}{ }^{16}$ also reported that pain duration during treatment was significantly longer in their unhealed group than in the healed group in patients with duodenal ulcers being treated with antacids. Ippoliti et al, ${ }^{25}$ however, reported that there was no correlation between the pain duration and ulcer healing. Similarly, in a study ${ }^{26}$ we found that if symptoms persisted one week after the start of treatment with cimetidine gastric ulcer healing would be delayed. What this means is not clear at present but it is possible that this finding is associated with acid hypersecretion.

Smoking has been found to delay the healing of duodenal ulcer in various treatment regimens such as placebo, ${ }^{127}$ trimipramine, ${ }^{28}$ antacids, ${ }^{9} 1629$ sulpiride, ${ }^{30}$ carbenoxolone, ${ }^{31}$ cimetidine, ${ }^{29} 323$ ranitidine, ${ }^{34}$ oxmetidine, ${ }^{32}{ }^{33}$ and omeprazole, ${ }^{35}$ though there are a few exceptions. ${ }^{31536}$ This adverse effect was reported to be nullified with misoprostol, a synthetic prostaglandin $E_{1}{ }^{37}$ and sucralfate. ${ }^{38}$ The data supporting a particular advantage for any specific drug in smokers are too limited, however, to allow firm conclusions to be drawn. ${ }^{39}$ In this study, patients who smoked more than 20 cigarettes daily during treatment had a significantly lower healing rate 
TABLE VI Healing rate and number of unfavourable factors in phase 2 patients with duodenal ulcer

\begin{tabular}{|c|c|c|c|c|}
\hline \multirow[b]{2}{*}{ Patients group } & \multicolumn{4}{|c|}{ Score } \\
\hline & 0 & 1 & 2 & 3 \\
\hline $\begin{array}{l}\text { Healed ulcer } \\
\text { Unhealed ulcer } \\
\text { Healing rate (\%) }\end{array}$ & $\begin{array}{c}32 \\
4 \\
88 \cdot 9\end{array}$ & $\begin{array}{c}11 \\
9 \\
55.0\end{array}$ & $\begin{array}{l}0 \\
5 \\
0\end{array}$ & $\begin{array}{l}\mathbf{0} \\
\mathbf{0} \\
\mathbf{0}\end{array}$ \\
\hline
\end{tabular}

$\mathrm{p}<0.001$

than those without this habit. There were no differences in healing rates between those who smoked less than nine cigarettes daily and those who smoked 10 to 19 cigarettes daily in our study. Hetzel $e t a^{33}$ reported that light smoking (less than 9 cigarettes daily), as opposed to heavier consumption, had no adverse effect on the healing rate of duodenal ulcer in patients being treated with cimetidine or ranitidine. Thus, it seems that heavy smoking (more than 20 cigarettes daily) has an adverse effect on healing. There was some effect of reducing cigarettes in heavy smokers but the values did not reach the threshold of significance, probably due to the small number of heavy smokers.

Various mechanisms have been proposed for the adverse effects of smoking on ulcer disease, including increased gastric emptying promoting duodenal acidification, increased basal and maximal acid secretion, decreased pancreatic bicarbonate secretion, altered gastroduodenal motility leading to reflux of duodenal contents, increased pepsinogen I secretion, altered blood flow, ${ }^{40-42}$ and decreased gastric mucosal prostaglandin production. ${ }^{434}$

With regard to the endoscopic data, stenosis of the duodenal bulb had a significant delaying effect on ulcer healing. This is consistent with the results of Massarrat et al, ${ }^{16}$ though Lam and $\mathrm{Koo}^{4}$ and Bardhan ${ }^{3}$ found no association between deformity of the duodenal bulb and healing. Deformity of the duodenal bulb had a strong correlation with a past history of duodenal ulcer $(\mathrm{r}=0.404, \mathrm{p}<0.01)$. Ulcer recurrence would cause narrowing of the duodenal bulb and probably leads to the ulcer becoming an intractable one, as is the case in gastric ulcer. ${ }^{1026}$

Reports on the effect of age, sex, and family history of ulcer disease on duodenal ulcer healing have been controversial. ${ }^{1349151619}$ Reports on the effect of the duration of the present ulcer pain, ${ }^{916}$ late age of onset of disease, ${ }^{417}$ alcohol consumption, ${ }^{14915}$ ulcer size, ${ }^{14161719}$ acid hypersecretion, ${ }^{3916171936}$ and nocturnal hypersecretion of acid $^{45-47}$ on the healing of duodenal ulcer have also been conflicting. In the present study, age; sex; basis of treatment; the duration of ulcer pain; past history of ulcer disease; alcohol consumption; and ulcer size, depth, and stage classification did not affect ulcer healing.

1 Sonnenberg A, Müller-Lissner SA, Vogel E, et al. Predictors of duodenal ulcer healing and relapse. Gastroenterology 1981; 81: 1061-7.

2 Pounder RE. What is an intractable duodenal ulcer and how should it be managed? Aliment Pharmacol Therap 1987; 1: 439-46.

3 Bardhan KD. Refractory duodenal ulcer. Gut 1984; 25: 711-7.

4 Lam SK, Koo J. Accurate prediction of duodenal-ulcer healing rate by discriminant analysis. Gastroentetology 1983; 85: 403-12.

5 Sakita T, Fukutomi T. Endoscopic diagnosis. In: Yoshitomi Y, ed. Ulcers of stomach and duodenum. Tokyo: Nankodo Co, 1971: 197-208.
6 Miyake T, Suzaki T, Oishi M. Correlation of gastric ulcer healing features by endoscopy, stereoscopic microscopy, and histology, and a reclassification of the epithelial regenerative process. Dig Dis Sci 1980; 25: 8-14.

7 Snedecor GW, Cochran WG. Statistical methods. 6th ed. Ames, Iowa: Iowa State University Press, 1967: 381-446.

8 Nie NN, Hull CH, Jenkins JG, Steinbrenner K, Dent DH. Statistical package for the social sciences. New York: McGrawHill, 1975 .

9 Massarrat S, Eisenman A. Factors affecting the healing rate of duodenal and pyloric ulcers with low-dose antacid treatment. Gut 1981; 22: 97-102.

10 Okada M, Yao T, Fuchigami T, Imamura K, Omae T. Factors influencing the healing rate of gastric ulcer in hospitalised subjects. Gut 1984; 25: 881-5.

11 Dorn HF. The relationship of cancer of the lung and the use of tobacco. Am Statist 1954; 8: 7-13.

12 Thomson ABR, Mahachai V. Medical management of uncomplicated peptic ulcer disease. In: Berk JE, ed. Bochus gastroenterology. Volume 2, 4th ed. Philadelphia: Saunders, 1985: 1116-54.

13 Nakajima T. Studies on factors affecting healing of gastric ulcer. Am $\mathcal{F}$ Gastroenterol 1976; 66: 150-4

14 Battaglia G, Mario FD, Piccoli A, Vianello F, Farinati F, Naccarato R. Clinical markers of slow healing and relapsing gastric ulcer. Gut 1987; 28: 210-5.

15 Lux G, Hentschel H, Rohner HG. Treatment of duodenal ulcer with low-dose antacids. Scand $\mathcal{f}$ Gastroenterol 1986; 21 : 1063-8.

16 Massarrat S, Muller HG, Shmitz-Moormann P. Risk factors for healing of duodenal ulcer under antacid treatment: do ulcer patients need individual treatment? Gut 1988; 29: 291-7.

17 Lam SK, Lai CL, Lee LNW, Fok KH, Ng MMT, Siu KF. Factors influencing healing of duodenal ulcer. Control of Factors influencing healing of duodenal ulcer. Control of pocturnal secretion by $\mathrm{H}_{2}$ blockade and characteristics

18 Van Deventer GM, Schneidman D, Walsh JH. Sucralfate and cimetidine as single agents and in combination for treatment of active duodenal ulcers. $A m \mathcal{F}$ Med 1985; 79 (suppl 2C): 39 44.

19 Gugler R, Jensen JC, Rohner HG, Reimnitz P, Somogyi A. Factors predicting the therapeutic outcome of duodenal ulcer treatment with $\mathrm{H}_{2}$-recepter antagonists. Klin Wochenschr 1985; 63: 1152-9.

20 Harvey RF, Bradshaw JM. A simple index of Crohn's-disease activity. Lancet 1980; i: 514

21 Myren J, Bouchier IAD, Watkinson G, Softley A, Clamp SE, de Dombal FT. The OMGE multinational inflammatory bowel disease survey: a report on 2657 cases. In: de Dombal FT, Myren J, Bouchier IAD, Watkinson G, eds. Inflammatory bowel disease. Oxford: Oxford Univ Press, 1986: 303-59.

22 Best WR, Becktel JM, Singleton JW, Kern F. Development of a Crohn's activity index. National cooperative Cróhn's a Crohn's activity index. National cooperative
disease study. Gastroenterology 1976; 70: 439-44.

23 Bonfils S, Baron JH, Blum A. Uncontrolled factors in controlled trials of peptic ulcer. Dig Dis Sci 1984; 29: 858-61.

24 Piarson RM. Who is taking their tablet? Br Med $\mathcal{F} 1982 ; 285$ : 757-8.

25 Ippoliti $\dot{A}$, Elashoff J, Valenzuela J, et al. Recurrent ulcer after successful treatment with cimetidine or antacid. Gastroenterology 1983; 85: 875-80.

26 Okada M, Yao T, Imamura K, et al. Factors influencing the healing rate of gastric ulcer under treatment with cimetidine. Am $\mathcal{F}$ Gastroenterol 1989; 84: 501-5.

27 Peterson WL, Sturdevant RAL, Frankl HD, et al. Healing of duodenal ulcer with an antacid regimen. $N$ Englf Med 1977; 297: 341-5.

28 Valnes K, Wetterhaus S, Ellekjaer E, et al. Trimipramine in treatment of duodenal ulcer. A multicenter open study. Scand F Gastroenterol 1980; 15: 65-70.

29 Korman MG, Shaw RG, Hansky J, Schmidt GT, Stern AI. Influence of smoking on healing rate of duodenal ulcer in response to cimetidine or high-dose antacid. Gastroenterology 1981; 80: 1451-3.

30 Lam SK, Lam KC, Lai CL, Yeung CK, Yam LYC, Wong WS. Treatment of duodenal ulcer with antacid and sulpiride. Gastroenterology 1979; 76: 315-22.

31 Young GP, St John DJB, Conventry DA. Treatment of duodenal ulcer with carbenoxolone sodium: a doublemasked endoscopic trial. Med f A ust 1979; 1: 2-5.

32 Korman MG, Hansky J, Eaves ER, Schmidt GT. Influence of cigarette smoking on healing and relapse in duodenal ulcer disease. Gastroenterology 1983; 85: 871-4.

33 Hetzel DJ, Korman MG, Hansky J. The influence of smoking on the healing of duodenal ulcer treated with oxmetidine or cimetidine. Aust N Z F Med 1983; 13: 587-90.

34 Korman MG, Hansky J, Merrett AC, Schumidt GT. Ranitidine in duodenal ulcer. Incidence of healing and effect of smoking. Dig Dis Sci 1982; 27: 712-5.

35 Classen M, Dammann HG, Downschke W, et al. Shortduration treatment of duodenal ulcer with omeprazole and duration treatment of duodenal ulcer with omeprazole and Med Wochenschr 1985; 110: 210-5.

36 Hetzel DJ, Hansky J, Shearman DJC, et al. Cimetidine treatment of duodenal ulceration. Short term clinical trial and maintenance study. Gastroenterology 1978; 74: 389-92.

37 Lam SK, Law WY, Choi TK, et al. Prostaglandin $\mathbf{E}_{1}$ (misoprostol) overcomes the adverse effect of chronic cigarette smoking on duodenal ulcer healing. Dig Dis Sci 1986; 31 (suppl): 68-74.

38 Lam SK, Hui WM, Lau WY, et al. Sucralfate overcomes adverse effect of cigarette smoking on duodenal ulcer healing and prolongs subsequent remission. Gastnoenterology 1987; 92: 1193-201. 
39 Hawkey CJ, Walt RP. Misoprostol, smoking and duodenal ulcer healing rates [Letter]. Lancet 1987; i: 393.

40 Sontag S, Graham DY, Belsito A, et al. Cimetidine, cigarette smoking, and recurrence of duodenal ulcer. $N$ Engl $\mathcal{Y} M e d$ 1984; 311: 689-93.

41 Müller-Lisser SA. Bile reflux is increased in cigarette smokers. Gastroenterology 1986; 90: 1205-9.

42 Massarrat S, Enshai F, Pittner PM. Increased gastric secretory capacity in smokers without gastrointestinal lesions. Gut 1986; $27: 433-9$.

43 Quimby GF, Bonnice CA, Burstein SH, Eastwood GL. Active smoking depresses prostaglandin synthesis in human gastric mucosa Ann Intern Med 1986; 104: 616-9.
44 McCready DR, Clark L, Cohen MM. Cigarette smoking reduces human gastric luminal prostaglandin $\mathrm{E}_{2}$. Gut 1985 ; 26: 1192-6.

45 Gledhill T, Buck M, Paul A, Hunt RH. Cimetidine or vagotomy? Comparison of the effects of proximal gastric vagotomy? Comparison of the effects of proximal gastric
vagotomy, cimetidine and placebo on nocturnal intragastric activity and acid secretion in patients with cimetidine activity and acid secretion in patients with cin
resistant duodenal ulcer. $B r \mathcal{F}$ Surg 1983; 70: 704-6.

46 Savarino V, Nela GS, Scalabirini P, Celle G. $\mathrm{H}_{2}$-receptor antagonist non-responders. Lancet 1987; ii: 1281.

47 Johnston D, Wormsley KG. $\mathrm{H}_{2}$-receptor antagonist nonresponders. Lancet 1988; i: 129. 